\title{
Root Responses to Short-Lived Pulses of Soil Nutrients and Shoot Defoliation in Seedlings of Three Rangeland Grasses
}

\author{
José Tulio Arredondo ${ }^{1}$ and Douglas A. Johnson ${ }^{2}$ \\ Authors are ${ }^{1}$ Scientist, División de Ciencias Ambientales, Instituto Potosino de Investigación Científica y Tecnológica, San Luis Potosí, SLP, México; and \\ ${ }^{2}$ Plant Physiologist, USDA-ARS Forage and Range Research Lab, Utah State University, Logan, UT 84322-6300, USA.
}

\begin{abstract}
Root proliferation is important in determining root foraging capability of rangeland grasses to unpredictable soil-nutrient pulses. However, root proliferation responses are often confounded by the inherent relative growth rate (RGR) of the particular species being compared. Additionally, inherent biomass allocation to roots (R:S ratio) can be associated with root RGR, hence likely influencing root foraging responses. The influence of relative growth rate and biomass allocation patterns on the speed and efficiency of root foraging responses at the critical seeding stage was examined in two important perennial rangeland grasses that occur widely in the Great Basin Region of the United States (Whitmar bluebunch wheatgrass [Psendoroegneria spicata \{Pursh\} Löve] and Hycrest crested wheatgrass [Agropyron desertorum \{Fisch. ex Link\} Schult. $\times$ A. cristatum L. Gaert.]) as well as in the widespread exotic invasive annual grass, cheatgrass (Bromus tectorum L.). Greenhouse-grown seedlings were exposed to four nutrient regimes: uniform-low, uniform-high, soil-nutrient pulse, soil-nutrient depletion, and to either no clipping or clipping $(80 \%$ removal of standing shoot biomass). Hycrest was the only species that exhibited root proliferation responses to the shortlived nutrient pulse, and this response occurred through root elongation rather than initiation of lateral root branches. Overall, defoliation inhibited proliferation-based root responses to a larger extent than topological-based root responses. Defoliated plants of Hycrest interrupted root development (topological index did not change) following shoot defoliation compared to undefoliated plants. In contrast, root topological developmental patterns were the same for defoliated and undefoliated plants of Whitmar, whereas cheatgrass exhibited an intermediate response between Whitmar and Hycrest. Our results suggest that inherent biomass allocation to roots contributes to enhanced capabilities of proliferation-based root responses.
\end{abstract}

\section{Resumen}

La proliferacion de raicez es importante al determinar la habilidad de los pastos para buscar los nutrientes en el suelo aún a pesar de cambios impredecibles. Sin embargo, las respuestas de propagacion de raíces a menudo se confunde con el crecimiento relativo intrínseco de una especie en particular al compararla con otra. Además, la distribución natural de la biomasa de la raíz (relación de R:S) puede relacionarse con la RGR de la raíz, e influenciar la respuesta de la búsqueda de nutrientes de la raíz. Se estudió la influencia de la velocidad del crecimiento relativo del patrón de distribución de la biomasa en la velocidad y eficiencia de las respuestas a la búsqueda de nutrientes de la raíz durante el estado crítico de plántula en dos pastos perenes muy importantes que ocurren ampliamente en la Región del Great Basin, U.S.A.(Whitmar bluebunch wheatgrass [Psendoroegneria spicata \{Pursh\} Löve] y Hycrest crested wheatgrass [Agropyron desertorum \{Fisch. ex Link\} Schult. $\times$ A. cristatum L. Gaert.]) así como un pasto anual, el bromillo (Bromus tectorum L.), que es invasivo y ampliamente distribuido. Plántulas producidas en un invernadero se expusieron a cuatro regímenes de nutrientes: Uniforme-bajo, uniforme-alto, cambios en los nutrientes del suelo, reducción en los nutrientes del suelo, y cortes o sin cortes (remoción del 80\% de la biomasa). El triguillo crestado (Hycrest) fue la única especie que presentó respuesta en la propagación en la raíz debido a la breve disponibilidad de nutrientes. Esta respuesta ocurrió a través del alargamiento de la raíz en lugar de la iniciación del crecimiento lateral de la raíz. En general, la defoliación reduce más la respuesta basada en la proliferación de la respuesta de la raíz en un mayor grado que la respuesta basada en la topología de la raíz. Las plantas defoliadas del triguillo crestado interrumpieron el desarrollo de la raíz (el índice topológico no cambia) después de la defoliación comparada con la plantas no defoliadas. En contraste, los patrones del desarrollo topológico de la raíz fueron similares para las plantas defoliadas y las no defoliadas de Whitmar, mientras que para el bromillo presentó una respuesta intermedia entre Whitmar y Hycrest. Nuestros resultados sugieren que la distribución natural de la biomasa de la raíz contribuye a incrementar la habilidad en la respuesta a la proliferación de las raíces.

Key Words: Agropyron cristatum, Agropyron desertorum, Bromus tectorum, clipping, nutrient-enriched soil patches, Pseudoroegneria spicata, root foraging, soil-nutrient heterogeneity, soil resources

Mention of a proprietary product does not constitute a guarantee or warranty of the product by US Dept of Agriculture, Utah State University, or the authors, and does not imply its approval to the exclusion of other products.

At the time of the research, José Tulio Arredondo was a graduate student in the Dept of Rangeland Resources, Utah State University, Logan, UT, USA.

Correspondence: J. T. Arredondo, Instituto Potosino de Investigación Científica y Tecnológica, Camino Presa de San José 2055 Lomas 4ta sección, 78261, San Luis Potosí, SLP, México. Email: tulio@ipicyt.edu.mx

Manuscript received 10 June 2008; manuscript accepted 23 June 2009.

\section{INTRODUCTION}

Differential root foraging responses for soil resources among species have been associated with several intrinsic root traits and their phenotypic plasticity, including root tissue density, specific root length, root xylem cross-sectional area, root longevity, and nutrient-uptake kinetics (Eissenstat et al. 2000; Hummel et al. 2007). However, the relationship between root 
foraging responses and root proliferation is still unclear. For example, Aanderud et al. (2003) suggested that species inherent differences in relative growth rate (RGR) may influence species root foraging capabilities. Thus, when roots proliferate into nutrient-rich microsites, root and shoot growth rates increase, and consequently root foraging is enhanced because of greater root biomass and root extension (Fransen et al. 1999). As a result, comparison of foraging responses among species could be masked by their inherent RGR. Because of this, Aanderud et al. (2003) recommended examining root foraging responses to nutrient pulses by removing the RGR effect. Empirical support for this RGR hypothesis was provided by Aanderud et al. (2003) and Kembel and Cahill (2005), who showed that fastgrowing species allocated more roots into nutrient-enriched soil patches than slow-growing species.

A related aspect that has not been fully examined relates to species-specific patterns of root and shoot biomass allocation (R:S ratio) and its relation to root and shoot RGR (Aiken and Smucker 1996). In general, nutrient-limited soil conditions favor plant allometries that have a proportionally large biomass allocation to roots compared to shoots (Tilman 1988). In addition, empirical evidence has shown that environmental conditions that affect soil-resource availability, such as variation in precipitation and temperature, may trigger changes in R:S (Mokany et al. 2006). Thus, large plasticity in a plant's $\mathrm{R}: \mathrm{S}$ allocation pattern may potentially reduce the competitive advantage of fast-growing species for soil-resource acquisition.

In semiarid rangelands, the seedling stage is a vulnerable phase in the life history of many plant species. In addition, herbivory is recognized as a major cause of seedling mortality (Crawley 1983). Several studies have reported the effect of seedling herbivory in modifying plant succession and plant community structure (Brown and Gange 1992; Davidson 1993; Hulme 1996). For rangeland grasses, grazing and soil-nutrient availability are factors that might trigger changes in root morphology. Although a nutrient pulse may trigger root growth and root proliferation (Jackson and Caldwell 1989; Bilbrough and Caldwell 1997), defoliation in contrast may cause cessation of root growth for a period of time (Caldwell et al. 1981; Richards 1984), which may allow the recovery of leaf area and photosynthetic activity in the plant (Crider 1955; Caldwell et al. 1981). Root foraging as a function of multiple factors is still poorly understood in rangeland grasses (Bilbrough and Caldwell 1995; Arredondo and Johnson 1999; Dawson et al. 2003).

In this study, we examined root morphological and topological responses in two important perennial rangeland grasses that occur widely in the Great Basin Region of the western United States: Whitmar bluebunch wheatgrass (Pseudoroegneria spicata [Pursh] Löve) and Hycrest crested wheatgrass (Agropyron desertorum [Fisch. ex Link] Schult. $\times A$. cristatum L. Gaert.). Whitmar and Hycrest exhibit similar whole-plant RGR (range of $0.36-0.41 \mathrm{~g} \cdot \mathrm{g}^{-1} \cdot \mathrm{d}^{-1}$, respectively) for 5-wk-old seedlings (Arredondo et al. 1998). Hycrest, however, exhibits a greater R:S ratio than Whitmar, which is explained by a higher root RGR (Arredondo et al. 1998). We compared the root responses of these two perennial grasses to that of a widespread exotic invasive annual grass, cheatgrass (Bromus tectorum L.), which has a whole-plant RGR that exceeds both Hycrest and Whitmar by about $20 \%\left(0.51 \mathrm{~g} \cdot \mathrm{g}^{-1}\right.$ $\cdot \mathrm{d}^{-1}$ ) for 5-wk-old seedlings (Arredondo et al. 1998). Despite these differences in whole-plant RGR, the root RGR values for Hycrest and cheatgrass were similar $\left(0.24\right.$ and $0.26 \mathrm{~g} \cdot \mathrm{g}^{-1}$. $\mathrm{d}^{-1}$, respectively). As a result, values of root RGR were $51 \%$, $59 \%$, and $55 \%$ of whole-plant RGR for cheatgrass, Hycrest, and Whitmar, respectively.

In this study, we were interested in testing the hypothesis that species with a large biomass allocation to roots (high R:S ratio), such as Hycrest and cheatgrass, are more effective at root foraging following a pulse of soil nutrients compared to a species with a low R:S ratio such as Whitmar. Additionally, we wanted to determine if shoot defoliation preferentially inhibits root proliferation-based responses compared to topologicalbased responses when plants are exposed to soil-nutrient pulses in these three important rangeland grasses.

\section{MATERIALS AND METHODS}

\section{Procedures}

The three grasses included in this study were Whitmar (a cultivar of bluebunch wheatgrass), Hycrest (a cultivar of hybrid crested wheatgrass), and cheatgrass (an exotic invasive annual grass). The study was conducted in a greenhouse at Logan, Utah, during November and December. No artificial light was provided, daylight air temperatures ranged between $20^{\circ} \mathrm{C}$ and $25^{\circ} \mathrm{C}$, and night-time temperatures were between $8^{\circ} \mathrm{C}$ and $12^{\circ} \mathrm{C}$. Seeds of Whitmar, Hycrest, and cheatgrass (obtained from a site near Pullman, Washington) were germinated on moistened blotter paper at $25-30^{\circ} \mathrm{C}$. Five equally sized seedlings with $1-\mathrm{cm}$ to $2-$ $\mathrm{cm}-$ long radicles were transplanted to plastic pots $(23 \mathrm{~cm}$ height, $24 \mathrm{~cm}$ diameter $\approx 10 \mathrm{~L}$ volume) that contained $8 \mathrm{~kg}$ of fine washed sand. Seedlings were thinned to one plant per pot after the second leaf emerged. We established 288 pots with the following treatments: three grass species, four nutrient treatments, two defoliation treatments, and three harvests; each treatment combination was replicated four times.

Sand in the pots was irrigated with about $2 \mathrm{~L}$ of either $32.2 \%$ (high concentration, $\mathrm{H}$ ) or $3.2 \%$ (low concentration, $\mathrm{L}$ ) full-strength Rorison nutrient solution (Table 1; Hewitt 1966). The nutrient solution was added to approximate a replenishment rate of about $2.5 \mathrm{~L} \cdot \mathrm{d}^{-1}$ per $100 \mathrm{~L}$ of water $(50 \mathrm{~mL}$. pot $^{-1}$; Hewitt 1966). Soil nutrient treatments consisted of two homogeneous and two heterogeneous treatments. The homogeneous low- and high-nutrient solutions represented two control treatments of well (high-high, $\mathrm{H}-\mathrm{H}$ ) and poorly (low-low, L-L) nourished plants. The short-lived nutrient pulse treatment (low-high, L-H) consisted of the application of a low-nutrient solution during the first $20 \mathrm{~d}$ followed by the application of a high-nutrient solution. We also included a pulse-depletion treatment to examine the effect of plant nutrient status (nutrient storage) on root growth and development. In this case, plants received initially a high-nutrient solution that was switched to a low-nutrient solution (highlow, H-L) after the first $20 \mathrm{~d}$. Pots receiving H-L treatments were leached with deionized water on day 20 and then supplied with a low-nutrient solution thereafter. Pots subjected to homogeneous nutrient treatments received either a highnutrient $(\mathrm{H}-\mathrm{H})$ or a low-nutrient $(\mathrm{L}-\mathrm{L})$ solution throughout the entire experiment. 
Table 1. Ion components of a full-strength Rorison nutrient solution and corresponding ion amounts for a high (32\%) and a low (3.2\%) nutrient solution used in this study.

\begin{tabular}{lccc}
\hline $\begin{array}{l}\text { Ions of full-strength } \\
\text { Rorison nutrient } \\
\text { solution }\end{array}$ & $\begin{array}{c}\text { Amount } \\
\left(\mathrm{mg} \cdot \mathrm{L}^{-1}\right)\end{array}$ & $\begin{array}{c}\text { High concentration } \\
\text { of full strength } \\
\left(\mathrm{mg} \cdot \mathrm{L}^{-1}\right)\end{array}$ & $\begin{array}{r}\text { Low concentration } \\
3.2 \% \text { of full strength } \\
\left(\mathrm{mg} \cdot \mathrm{L}^{-1}\right)\end{array}$ \\
\hline $\mathrm{N}-\mathrm{NO}_{3}^{-}$ & 56 & 17.92 & 1.79 \\
$\mathrm{P}-\mathrm{PO}_{4}^{-}$ & 31 & 9.98 & 0.99 \\
$\mathrm{~K}^{+}$ & 78 & 24.96 & 2.49 \\
$\mathrm{Ca}^{+2}$ & 80 & 25.6 & 2.56 \\
$\mathrm{~S}^{-\mathrm{SO}_{4}^{-2}}$ & 32 & 10.24 & 1.02 \\
$\mathrm{Fe}^{+3}$ & 3 & 0.96 & 0.096 \\
$\mathrm{Mn}^{+2}$ & 0.5 & 0.16 & 0.016 \\
$\mathrm{Cu}^{+2}$ & 0.1 & 0.032 & 0.0032 \\
$\mathrm{Zn}^{+2}$ & 0.1 & 0.032 & 0.0032 \\
$\mathrm{~B}^{+3}$ & 0.5 & 0.16 & 0.016 \\
$\mathrm{Mo}^{+6}$ & 0.1 & 0.032 & 0.0032 \\
\hline
\end{tabular}

Water loss in pots through evaporation and transpiration was replenished every other day by adding up to $150 \mathrm{~mL}$ of deionized water (including the nutrient solution), as determined by weekly weighing of pots. The nutrient solution was only adjusted according to the treatment and not for changes in seedling size. The low- and high-nutrient solutions represented nitrogen and phosphorus concentrations slightly lower and higher, respectively, than typically occur in rangeland soils (refer to Table 1). The high-nutrient treatment $(\mathrm{H})$ represented a typical high-nutrient patch $\left(<10 \mathrm{mg} \cdot \mathrm{L}^{-1}\right.$ bicarbonateexchangeable phosphate, $<5 \mathrm{mg} \cdot \mathrm{L}^{-1}$ available nitrate, Jackson and Caldwell 1991) found in rangeland soil (Jackson and Caldwell 1993). For the defoliation treatments, $80 \%$ of standing biomass was removed on day 20 in half of the pots, the day when the nutrient solutions were applied for the second time. We applied a severe defoliation treatment to ensure plant limitation in carbon for shoot and root growth. Four replicates per treatment were harvested at $3 \mathrm{~d}, 8 \mathrm{~d}$, and $13 \mathrm{~d}$ after the second application of nutrient solutions, and the defoliation treatment was applied. Repeated harvests allowed short-term root responses to be examined in each treatment combination, and relationships among root morphological and topological traits were evaluated by regression analysis.

The duration of seedling establishment was defined based on the results of a previous study, when plant size and total seedling RGR in all three species were similar after $20 \mathrm{~d}$ (see fig. 1 in Arredondo et al. 1998) and a minimum number of four to six mature leaves developed. For the harvests, sand was carefully removed from the root systems with a fine spray of water, and the shoots were severed and oven-dried at $70^{\circ} \mathrm{C}$ for $48 \mathrm{~h}$ to constant mass to determine shoot dry matter. Root systems were immediately stored in a cold room at $2-4^{\circ} \mathrm{C}$. The complete root systems, including no less than two root axes (depending on the harvest) were dyed with Toluidine blue and then spread with no overlapping intersections on transparent acetate sheets with the use of dissecting needles. The spread root systems were photocopied, removed from the acetate sheets, oven-dried at $70^{\circ} \mathrm{C}$ to constant weight, and root dry matter was determined. A digitized image of the entire root system was obtained with a flatbed scanner (Silverscanner, LaCie, Portland, OR) with a resolution of 300 dots per inch. Each image was analyzed with the Branching v1.52 software (Berntson 1992). No examination of the bias due to photocopying or digital manipulation of images was carried out. The following root morphological characteristics were evaluated: number of lateral roots, diameter of main axis and lateral roots, total root length, and root biomass.

\section{Root Architecture Terminology}

The Branching software (Berntson 1992) allowed estimations of root topological parameters, using the nomenclature and algorithms of Fitter (1985) after Werner and Smart (1973). In this system of classification, a link (segment of root between a meristem and a branching point, between two branching points, or between the base and a branching point) is the basic unit of the system (Figs. 1a and 1c). Links are classified as either external if they end as a terminal root or internal if they join another root. In a further classification, links are identified according to the type of links they join (Smart 1978). Thus, "EE" are external links that join other external links, "EI" are external links connected to internal links, "IE" are internal links attached to external links, and "II" are internal links (Fig. 1a). The parameter's magnitude ( $\mu$, number of external links in the system), altitude ( $a$, largest path of links from the root base to an exterior link meristem), and total exterior path length $\left(P_{e}\right.$, the sum of all link paths from each meristem to the base) were calculated from this link distribution (Fig. 1b).

Several topological indices were calculated from these parameters; in this study the $P_{e^{-}}$slope index (defined as the ratio of $P_{e}$ to $\mu$ ) was used to characterize root topology. The $P_{e^{-}}$ slope index indicates the complexity of branching in a root system; however, the interpretation of the $P_{e}$-slope index cannot be done independent of magnitude. The indices can depict topologies of roots between two extreme architectures: herringbone and dichotomous (Figs. $1 \mathrm{~b}$ and 1c). Theoretical values of the $P_{e}$-slope index for a herringbone pattern varies between 1.8 and 2.0 with a minimum of 1.806 for $n$ (i.e., the number of links) $=11$. For a dichotomous pattern, the $P_{e^{-}}$-slope index ranges between 1.0 and 1.8 (Werner and Smart 1973; Smart 1978). For these theoretical values, increasing magnitude produces a steady decline in minimum $P_{e^{-}}$-slope index, whereas the maximum for the $P_{e}$-slope index remains fairly constant. The difference between these theoretical values results in a monotonous value between 0 and 1 . This characteristic was used to build the topological index (TI), which was independent of magnitude, and calculated as

$$
\begin{aligned}
\mathrm{TI}= & {\left[\left(\log P_{e} / \log u\right)_{\text {observed }}-\left(\log P_{e} / \log u\right)_{\text {dichotomous }}\right] / } \\
& {\left[\left(\log P_{e} / \log u\right)_{\text {herringbone }}-\left(\log P_{e} / \log u\right)_{\text {dichotomous }}\right] . }
\end{aligned}
$$

For TI, values close to 1 represent a less complex root system (herringbone branching pattern), whereas values $<1$ indicate a more complex branching pattern (dichotomous branching pattern). A similar analysis can be applied to different link types (A. H. Fitter, personal communication, 2000) 


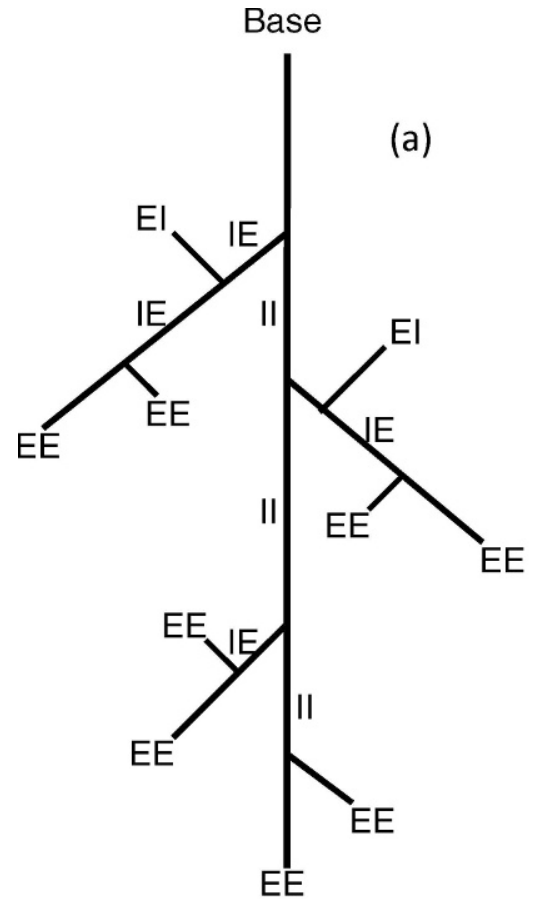

Link classification

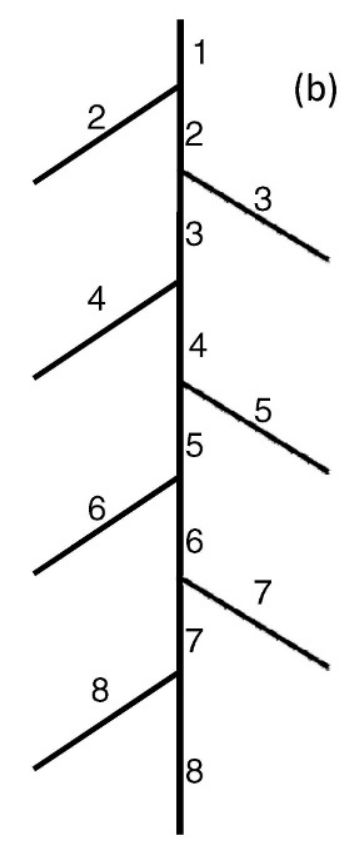

(b)

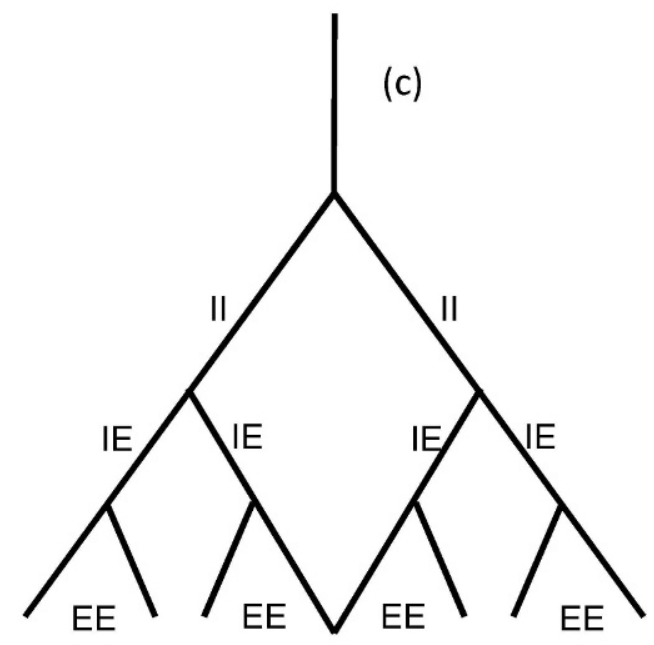

Dichotomous topology
Herringbone topology

$$
\begin{aligned}
& \text { Magnitude }=8 \\
& \text { Altitude }=8 \\
& \text { Exterior Pathlength }=43
\end{aligned}
$$

Figure 1. Diagrams showing a, the link classification system of Fitter (1985); $\mathbf{b}$, a herringbone topology and associated values for magnitude, altitude, and exterior path length of that system; and c, a dichotomous topology. Abbreviations: EE indicates external-external links; El, externalinternal links; IE, internal-external links; and II, internal-internal links.

\section{Statistical Analysis}

All data were tested for normality with the use of normal probability plots of residuals, stem-and-leaf diagrams, and the Shapiro-Wilk test (Zar 1984). Nonnormal data were logarithmically transformed to correct for deviations from normality. Data were analyzed as a factorial arrangement in randomized complete blocks with four replications. A general linear model was used to analyze the data (GLM procedure, SAS; Table 2). Because most of the analyzed root traits were size-dependent, meaningful comparisons of the root characteristics at similar sizes were performed through plotting root traits against root biomass as a proxy for size and comparing their slopes (Gunn et al. 1999). Similarly, roots contrasted at comparable magnitudes could achieve a similar topological index through different patterns of biomass allocation to roots. We examined this possibility by using a test for equality of slopes with TI as the response variable and root dry matter as the continuous variable or covariate (Table 3 ).

Power functions of the form $Y=a X$ and linear regressions were used to characterize allometric relationships (Niklas 1994) between root dry matter and root system topology and root length. Log-transformed, least-squared Type-I regressions were used to obtain the parameter values of the power function (Sokal and Rohlf 1981); scaling exponents were estimated as $r_{\mathrm{RMA}}=\alpha_{\mathrm{ls}} / r$, where $r_{\mathrm{RMA}}$ is the reduced major axis regression, $\alpha_{\mathrm{ls}}$ is the slope determined by least-squared regression, and $r$ corresponds to the regression coefficient. Confidence intervals for the regression coefficients were calculated and used for paired-slope comparisons.

\section{RESULTS}

\section{Root Morphology}

The number of lateral roots differed with species and nutrient treatments (Table 2, $P<0.01$; Fig. 2). For cheatgrass, fewer numbers of lateral roots were found in the initially low $(\mathrm{L}-\mathrm{H}$, $\mathrm{L}-\mathrm{L})$ treatments compared to the nutrient depletion $(\mathrm{H}-\mathrm{L})$ and homogeneous high $(\mathrm{H}-\mathrm{H})$ treatments. For Hycrest, the number of lateral roots did not differ after the pulse $(\mathrm{L}-\mathrm{H})$ and nutrientdepletion (H-L) treatment; however, the number of lateral roots was significantly lower in the initially low-nutrient treatments $(\mathrm{L}-\mathrm{L}, \mathrm{L}-\mathrm{H})$ than in the $\mathrm{H}-\mathrm{H}$ treatment. For Whitmar, the number of lateral roots was similar in all nutrient treatments. Cheatgrass had more lateral roots in the nutrientpulse $(\mathrm{L}-\mathrm{H})$ and nutrient-depletion $(\mathrm{H}-\mathrm{L})$ treatments compared to Hycrest and Whitmar, which had similar numbers. Number of lateral roots did not differ among species in the homogeneous low-nutrient $(\mathrm{L}-\mathrm{L})$ treatment. Defoliation did not influence the number of lateral roots in any species and nutrient treatment (Table 3), and with increasing seedling age the number of lateral roots increased similarly for all species across all other treatment combinations (Table 2, $P<0.01)$. 
Table 2. Sources of variation, degrees of freedom, and mean squares for number of lateral roots, diameter of main root axis and lateral roots, topological index $(\mathrm{TI})$, and root dry mass.

\begin{tabular}{|c|c|c|c|c|c|c|}
\hline Source of variation & $d f$ & $\begin{array}{l}\text { No. lateral } \\
\text { roots }\end{array}$ & $\begin{array}{l}\text { Diameter main root } \\
\text { axis }(\mu \mathrm{m})\end{array}$ & $\begin{array}{l}\text { Diameter lateral } \\
\text { roots }(\mu \mathrm{m})\end{array}$ & $\mathrm{TI}$ & $\begin{array}{l}\text { Root dry mass } \\
(\mathrm{mg})\end{array}$ \\
\hline Species $(S)^{1}$ & 2 & 133.7 & $0.0960^{* *}$ & $0.0527^{\star *}$ & $0.0619^{\star \star}$ & $0.6283^{* *}$ \\
\hline Defoliation (D) & 1 & 3.7 & $0.0024^{\star}$ & 0.0001 & $0.1049^{\star *}$ & $7.4699^{* *}$ \\
\hline Nutrients (N) & 3 & $68.2^{* *}$ & 0.0003 & 0.0001 & 0.0037 & $0.4291^{* *}$ \\
\hline$S \times D$ & 2 & 9.7 & 0.0002 & $0.0004^{*}$ & 0.0042 & 0.0706 \\
\hline$S \times N$ & 6 & $41.2^{\star \star}$ & 0.0007 & 0.0002 & 0.0040 & 0.1099 \\
\hline $\mathrm{D} \times \mathrm{N}$ & 3 & 14.1 & 0.0005 & 0.0001 & 0.0054 & $0.1873^{*}$ \\
\hline $\mathrm{S} \times \mathrm{D} \times \mathrm{N}$ & 6 & 20.4 & 0.0003 & 0.0001 & 0.0033 & 0.0702 \\
\hline Harvest $(\mathrm{H})$ & 2 & $14.4^{\star *}$ & $0.0088^{* *}$ & $0.0006^{\star}$ & $0.1529^{* *}$ & $7.3907^{\star * *}$ \\
\hline $\mathrm{H} \times \mathrm{S}$ & 4 & 28.2 & 0.0004 & 0.0000 & 0.0068 & $0.2150^{\star}$ \\
\hline$H \times D$ & 2 & 15.1 & 0.0007 & 0.0003 & $0.0155^{\star *}$ & $0.1352^{*}$ \\
\hline $\mathrm{H} \times \mathrm{N}$ & 6 & 5.5 & 0.0003 & 0.0002 & 0.0020 & 0.2096 \\
\hline $\mathrm{H} \times \mathrm{S} \times \mathrm{D}$ & 4 & 15.8 & 0.0009 & 0.0003 & 0.0016 & 0.0277 \\
\hline $\mathrm{H} \times \mathrm{S} \times \mathrm{N}$ & 12 & 13.8 & 0.0007 & 0.0001 & 0.0038 & 0.1490 \\
\hline $\mathrm{H} \times \mathrm{D} \times \mathrm{N}$ & 6 & 20.8 & 0.0001 & 0.0001 & 0.0039 & 0.0733 \\
\hline $\mathrm{H} \times \mathrm{S} \times \mathrm{D} \times \mathrm{N}$ & 12 & 9.7 & 0.0004 & 0.0001 & 0.0023 & - \\
\hline
\end{tabular}

${ }^{1}$ Significant differences for the source of variation are indicated by ${ }^{*}(P<0.05)$ and ${ }^{* *}(P<0.01)$.

Root diameter of the main root axes and lateral roots were largest for Hycrest followed by Whitmar and cheatgrass (data not shown for main axes; Table $2, P<0.01$ ). Diameters of both root types increased significantly with each successive harvest (Table 2, $P<0.01$ ). For all species and nutrient treatments, the diameter of the main root axes was larger in defoliated plants than nondefoliated plants (Table 2, $P<0.01$ ). For Whitmar, the diameter of lateral roots was significantly larger (by about $8 \%$ ) after defoliation $(P<0.05$, Table 3$)$ compared to nondefoliated plants; defoliation did not affect the diameter of lateral roots in cheatgrass or Hycrest. The amount of dry matter allocated to the root system was not associated with number of lateral roots, diameter of lateral roots, and diameter of the main root axis $(P>0.05$, Table 4). However, the number of root axes and total root length did change with changes in root dry matter (Table $4, P<0.05$ ). Overall, defoliated plants produced half the root length per unit root dry matter compared to undefoliated plants $\left(5.5 \pm 1.2 \mathrm{~cm} \cdot \mathrm{mg}^{-1}\right.$ and $11.4 \pm 1.2 \mathrm{~cm} \cdot \mathrm{mg}^{-1}$, respectively, $P<0.01, n=144)$. In comparing allocation rates of dry matter to root length (allocation efficiency of root production) with the use of an equality of slope test, we found significant differences in regression coefficients (allocation rates) depending on the particular nutrient treatment by species combination (Tables 4 and 5). For cheatgrass, allocation rates spanned a twofold range from $9.7 \mathrm{~cm} \cdot \mathrm{mg}^{-1}$ for the $\mathrm{L}-\mathrm{H}$ treatment to $18.5 \mathrm{~cm} \cdot \mathrm{mg}^{-1}$ for the $\mathrm{H}-\mathrm{L}$ treatment with intermediate allocation efficiencies for the homogeneous nutrient treatments $\left(\mathrm{H}-\mathrm{H}=12.0 \mathrm{~cm} \cdot \mathrm{mg}^{-1}, \mathrm{~L}-\mathrm{L}=10.6\right.$ $\mathrm{cm} \cdot \mathrm{mg}^{-1}$; Fig. 3a, $\left.P<0.05\right)$. For Hycrest, allocation efficiency in the $\mathrm{L}-\mathrm{H}$ treatment was significantly higher $\left(38.0 \mathrm{~cm} \cdot \mathrm{mg}^{-1}\right)$ than that for the other nutrient treatments $(\mathrm{H}-\mathrm{H}=13.0$ $\mathrm{cm} \cdot \mathrm{mg}^{-1}, \mathrm{H}-\mathrm{L}=15.0 \mathrm{~cm} \cdot \mathrm{mg}^{-1}, \mathrm{~L}-\mathrm{L}=18.0 \mathrm{~cm} \cdot \mathrm{mg}^{-1}$; Fig. 3b; Table 5). In contrast, Whitmar exhibited the highest allocation efficiency $\left(12.1 \mathrm{~cm} \cdot \mathrm{mg}^{-1}\right)$ in the $\mathrm{L}-\mathrm{L}$ treatment and the lowest in the $\mathrm{L}-\mathrm{H}$ treatment $\left(5.2 \mathrm{~cm} \cdot \mathrm{mg}^{-1}\right.$; Fig. $3 \mathrm{c}$; Table 5).

\section{Root Topology}

Significant differences were detected for TI among species, defoliation treatments, and harvests, but not among nutrient treatments (Table 2, $P<0.05$ ). A significant harvest by defoliation interaction indicated that developmental changes in root branching occurred at a lower rate for defoliated than undefoliated plants. However, because similar topologies can be achieved with different investments of root biomass, an equality-of-slopes test was conducted to compare TI at equivalent levels of root dry matter (Gunn et al. 1999) and to examine trade-offs between root growth and root topology. This analysis showed that TI (when adjusted for root dry matter) differed significantly among species, defoliation, and nutrient treatments (Table 4). In general, we observed a negative relationship between TI and root biomass, indicating that topological complexity increased proportionally with increases in root size.

Defoliation affected species rate of change in TI as roots increased in size (Table 4 , species $\times$ defoliation interaction). Regression analysis showed that all species, except defoliated Hycrest, fit a line with a slope different from zero $(P<0.01)$. For cheatgrass, a high slope for the scaling exponent of TI vs. root biomass suggested a delay in the development of root branching complexity for defoliated compared to nondefoliated plants at a similar root size (Fig. $4 \mathrm{a} ; r_{\mathrm{RMA}}=0.74 \pm 0.02$ and $0.66 \pm 0.02$, respectively). For defoliated Hycrest plants, TI remained the same despite modest increases in root dry matter $\left(P=0.45, r^{2}=0.01, n=48\right)$, whereas for nondefoliated plants branching complexity increased proportionally with root dry matter (Fig. $4 \mathrm{~b} ; r_{\mathrm{RMA}}=-0.7 \pm 0.02, P=0.0004, r^{2}=0.24$, $n=48$ ). For Whitmar, regression coefficients between TI and root dry matter were similar for defoliated and nondefoliated plants (Fig. $4 \mathrm{c} ; r_{\mathrm{RMA}}=0.67 \pm 0.02$ for both treatments).

\section{Plant Biomass}

Total plant biomass differed among species, soil nutrient, and defoliation treatments $(P<0.01$, Table 2$)$, and there was a 
Table 3. Means and standard errors for diameter of first-order lateral roots for cheatgrass, Hycrest, and Whitmar in undefoliated and defoliated plants.

\begin{tabular}{lcc}
\hline Species & Defoliation treatment & $\begin{array}{c}\text { Diameter of first order lateral roots } \\
(\mu \mathrm{m})\end{array}$ \\
\hline Cheatgrass & Undefoliated & $56.2 \pm 1.8 \mathrm{~d}$ \\
& Defoliated & $53.0 \pm 1.8 \mathrm{~d}$ \\
\multirow{2}{*}{ Hycrest } & Undefoliated & $99.3 \pm 1.8 \mathrm{a}$ \\
& Defoliated & $101.5 \pm 1.8 \mathrm{a}$ \\
\multirow{2}{*}{ Whitmar } & Undefoliated & $85.0 \pm 1.8 \mathrm{C}$ \\
& Defoliated & $92.0 \pm 1.8 \mathrm{~b}$ \\
\hline
\end{tabular}

${ }^{1}$ Different letters within a column indicate significant differences at $P<0.05$.

significant nutrient-by-defoliation treatment interaction. For nondefoliated plants, total biomass production was greater in the nutrient-pulse $(\mathrm{L}-\mathrm{H})$ treatment $(13.1 \pm 0.4 \mathrm{mg})$ than in the homogeneous low-nutrient (L-L) treatment $(11.3 \pm 0.4 \mathrm{mg})$. There was no difference in biomass production between the homogeneous high $(\mathrm{H}-\mathrm{H} ; 16.1 \pm 0.4 \mathrm{mg})$ and the nutrientdepletion (H-L; $15.2 \pm 0.4 \mathrm{mg})$ treatment. Defoliation reduced total biomass up to $50 \%$ compared to undefoliated plants in all nutrient treatments. Defoliated plants produced similar biomass in the nutrient-pulse (L-H; $5.9 \pm 0.4 \mathrm{mg}$ ), nutrientdepletion (H-L; $6.7 \pm 0.4 \mathrm{mg}$ ), and homogeneous low (L-L; $6.6 \pm 0.4 \mathrm{mg})$ nutrient treatments. Only the nutrient-pulse treatment $(\mathrm{L}-\mathrm{H})$ had a significantly lower biomass than the homogeneous high treatment $(\mathrm{H}-\mathrm{H} ; 7.1 \pm 0.4 \mathrm{mg})$, which had the highest total biomass. Additionally, for each nutrient treatment, we estimated the proportional change in total root length (TI), and number of root tips in defoliated as compared to undefoliated plants (Table 6). Total root length and number of root tips showed an overall decrease, whereas TI increased independently of nutrient treatment.

\section{DISCUSSION}

This study allowed us to differentiate root foraging mechanisms that were (in the case of Hycrest and Whitmar) independent of species-specific RGR. By testing two perennial grasses with similar RGR and one annual grass with higher total RGR at the early seedling stage, we could relate root growth to foraging root response mechanisms such as root proliferation due to a

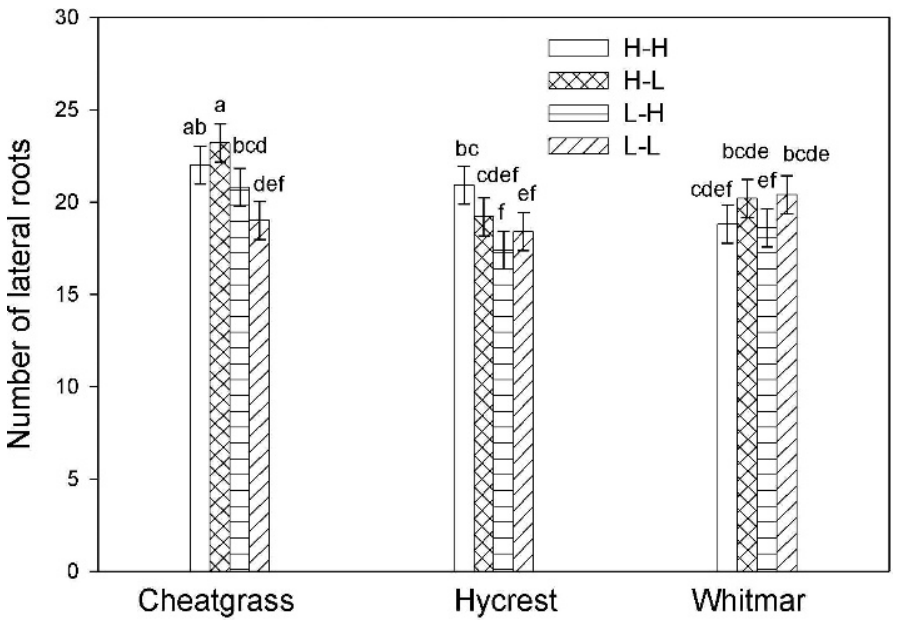

Figure 2. Number of first-order lateral roots for cheatgrass, Hycrest, and Whitmar exposed to four nutrient treatments, including uniformhigh $(\mathrm{H}-\mathrm{H})$, uniform-low $(\mathrm{L}-\mathrm{L})$, nutrient-pulse $(\mathrm{L}-\mathrm{H})$, and nutrientdepletion $(\mathrm{H}-\mathrm{L})$ treatments. Bars with different letters indicate significant differences at $P<0.05$, among nutrient treatments and species.

nutrient pulse. In our experimental setting, we compared root responses to a nutrient pulse with a control (L-L) treatment that was not favorable for plant growth, but also with a nutrient treatment $(\mathrm{H}-\mathrm{H})$ that provided conditions for maximum growth (Arredondo and Johnson 1999). If an inherently high RGR had prevailed, we would have observed greater root branch density and/or larger roots for either cheatgrass or Hycrest in the $\mathrm{H}-\mathrm{H}$ treatment. Regarding our hypothesis, our results suggested that species with inherently greater allocation to roots (high R:S ratio) could potentially be more efficient at deploying root length in response to nutrient pulses. Efficiency to deploy roots into enriched patches was monitored by plotting the root length produced per unit root biomass (specific root length [SRL]).

We initially proposed our hypothesis based on the growth analysis data reported by Arredondo et al. (1998) in which Hycrest and cheatgrass showed higher R:S and root RGR than Whitmar. In the present study, however, cheatgrass exhibited the lowest, Hycrest the intermediate, and Whitmar the highest R:S ratio $(0.30,0.40$, and 0.47 , respectively, $P<0.01)$. Root proliferation responses of Hycrest (Fig. 3b) observed in the present study did not correspond with our initial predictions of

Table 4. Sources of variation, degrees of freedom, and mean squares for a slope homogeneity test using root dry matter as a covariate and number of root axes, total root length, topological index $(\mathrm{TI})$, and external-external link length as dependent variables.

\begin{tabular}{|c|c|c|c|c|c|}
\hline Source of variation & df & No. root axes & Total root length & $\mathrm{TI}$ & External-external link length \\
\hline Root dry matter ${ }^{1}$ & 1 & $1.36^{\star *}$ & $7.66^{\star *}$ & $0.0758^{* *}$ & $0.4069^{* *}$ \\
\hline Species (S) & 2 & 0.00 & 0.03 & $0.0047^{\star *}$ & 0.0329 \\
\hline Defoliation (D) & 1 & 0.01 & $0.51^{\star \star}$ & $0.0052^{* *}$ & 0.0355 \\
\hline Nutrients (N) & 3 & $0.01^{*}$ & 0.02 & $0.0005^{\star *}$ & $0.1006^{\star *}$ \\
\hline$S \times D$ & 2 & 0.00 & 0.01 & $0.0029^{*}$ & 0.0197 \\
\hline $\mathrm{S} \times \mathrm{N}$ & 6 & 0.00 & $0.06^{\star \star}$ & 0.0008 & 0.0160 \\
\hline $\mathrm{D} \times \mathrm{N}$ & 3 & 0.00 & 0.04 & 0.0016 & 0.0460 \\
\hline $\mathrm{S} \times \mathrm{D} \times \mathrm{N}$ & 6 & 0.00 & 0.002 & 0.0005 & $0.0673^{*}$ \\
\hline
\end{tabular}

${ }^{1}$ Significant differences for the source of variation are indicated by ${ }^{*}(P<0.05)$ and ${ }^{* *}(P<0.01)$. 

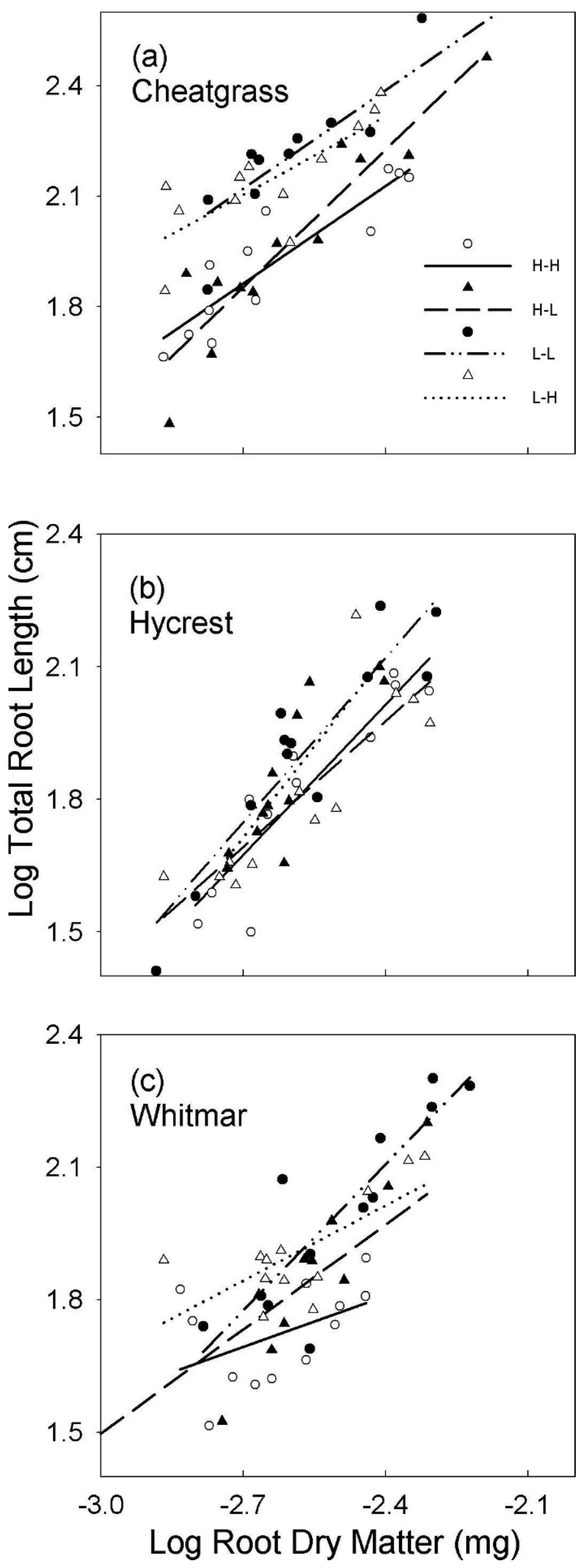

biomass allocation, but they did agree with the allocation patterns and root RGR reported by Arredondo and Johnson (1998). This lack of agreement for the R:S ratio in the present study may be because we estimated the $\mathrm{R}: \mathrm{S}$ ratio by averaging across four different soil-nutrient treatments. Because Arredondo et al. (1998) estimated the R:S ratio from grasses growing under soil conditions that provided maximum RGR, we examined R:S ratio under the uniform high treatment and still species exhibited the same pattern (cheatgrass $<\mathrm{Hy}$ crest $<$ Whitmar). In the nutrient-pulse treatment (L-H), root proliferation in Hycrest occurred through the allocation of $47 \%$ more root length per unit root biomass compared to the $\mathrm{L}-\mathrm{L}$ treatment (Fig. $3 \mathrm{~b}$ ). Root proliferation in this case was associated only with a greater efficiency in biomass allocation to root length and not with a greater number of lateral roots (Fig. 2). Although root proliferation responses were reported previously for crested wheatgrass (Jackson and Caldwell 1989), that study did not separate the contribution of root elongation and lateral root initiation mechanisms.

The largest SRL in the $\mathrm{L}-\mathrm{L}$ treatment by Whitmar (Fig. 3c) could be interpreted in terms of a growth strategy to improve soil exploration and soil-nutrient acquisition, and did not correspond to predictions related to capability to proliferate roots based on observed root and shoot allocation patterns. Despite its inherent high RGR, cheatgrass did not respond to the nutrient pulse; however, cheatgrass did exhibit the largest SRL and number of first-order lateral roots in the $\mathrm{H}-\mathrm{L}$ and $\mathrm{H}-\mathrm{H}$ treatments. Thus, it appears that cheatgrass responded rapidly to the initial high $(\mathrm{H})$ soil-nutrient condition through an increase of RGR, which led to rapid root growth. This rapid response by cheatgrass was consistent with field observations of Bilbrough and Caldwell (1997), who reported that cheatgrass exhibited the largest response to the first early-spring nutrient pulse.

We examined the fitness of root foraging responses as recommended by Kembel and Cahill (2005) by comparing total biomass production in the various soil-nutrient regimes. When averaged across species and defoliation treatments, we observed greater total biomass for the two initially high-nutrient treatments $(\mathrm{H}-\mathrm{H}, \mathrm{H}-\mathrm{L})$ compared to the two initially lownutrient treatments $(\mathrm{L}-\mathrm{L}, \mathrm{L}-\mathrm{H})$. We expected to observe greater fitness benefits in the $\mathrm{H}-\mathrm{H}$ treatment because it provided twice the amount of nutrients compared to the $\mathrm{H}-\mathrm{L}$ and $\mathrm{L}-\mathrm{H}$ treatments. However, greater total biomass in the H-L treatment suggested that the grasses in our study responded rapidly to an initially high-nutrient condition and then maintained growth, probably on stored nutrients (Chapin and Slack 1979).

The overall effect of defoliation in our study was to decrease plasticity of both root topology and root morphology, depending on grass species (Fig. 4). For Hycrest (a grazing-

$\leftarrow$

Figure 3. Least-square linear relationships between log of total root length and log of root dry matter for a, cheatgrass; $\mathbf{b}$, Hycrest; and c, Whitmar. Symbols correspond to data points from which regression lines were estimated for the four nutrient treatments, including uniformlow (L-L; open circles), uniform-high $(\mathrm{H}-\mathrm{H}$; solid circles), soil-nutrient pulse ( $\mathrm{L}-\mathrm{H}$; open triangles), and soil-nutrient depletion ( $\mathrm{H}-\mathrm{L}$; solid triangles). 
Table 5. Intercepts and slopes for least-squared Type-I linear regressions between total root length and root dry matter (top part of table), and the topological index ( $\mathrm{TI}$ ) and root dry matter (bottom part of table). Acronyms for nutrient treatments refer to uniform-low ( $\mathrm{L}-\mathrm{L})$, uniform-high (H-H), soil-nutrient pulse $(\mathrm{L}-\mathrm{H})$, and soil-nutrient depletion $(\mathrm{H}-\mathrm{L})$ treatments. Linear equations are derived from the equality of slopes test comparing species $\times$ nutrient and species $\times$ defoliation interactions presented in Table 3. Values for the regression equations are log transformed.

\begin{tabular}{|c|c|c|c|c|}
\hline Species & Soil nutrient treatment & Equation & $R^{2}$ & $P$ \\
\hline \multirow[t]{4}{*}{ Cheatgrass } & $\mathrm{H}-\mathrm{H}$ & $Y=4.44+0.95 X$ & 0.76 & 0.0001 \\
\hline & $\mathrm{H}-\mathrm{L}$ & $Y=5.04+1.18 X$ & 0.88 & 0.0001 \\
\hline & $L-L$ & $Y=4.33+0.81 X$ & 0.63 & 0.0001 \\
\hline & $\mathrm{L}-\mathrm{H}$ & $Y=4.17+0.76 X$ & 0.62 & 0.0001 \\
\hline \multirow[t]{4}{*}{ Hycrest } & $\mathrm{H}-\mathrm{H}$ & $Y=4.38+0.99 X$ & 0.77 & 0.0001 \\
\hline & $\mathrm{H}-\mathrm{L}$ & $Y=4.26+0.95 X$ & 0.64 & 0.0001 \\
\hline & $L-L$ & $Y=4.90+1.16 X$ & 0.83 & 0.0001 \\
\hline & $\mathrm{L}-\mathrm{H}$ & $Y=5.33+1.33 X$ & 0.72 & 0.0001 \\
\hline \multirow[t]{4}{*}{ Whitmar } & $\mathrm{H}-\mathrm{H}$ & $Y=3.54+0.69 X$ & 0.48 & 0.0001 \\
\hline & $\mathrm{H}-\mathrm{L}$ & $Y=3.76+0.75 X$ & 0.50 & 0.0001 \\
\hline & $L-L$ & $Y=4.28+0.91 X$ & 0.71 & 0.0001 \\
\hline & $\mathrm{L}-\mathrm{H}$ & $Y=3.53+0.63 X$ & 0.52 & 0.0001 \\
\hline Species & Defoliation treatment & Equation & $R^{2}$ & $P$ \\
\hline \multirow[t]{2}{*}{ Cheatgrass } & Defoliated & $Y=-0.29-0.07 X$ & 0.35 & 0.0001 \\
\hline & Undefoliated & $Y=-0.46-0.14 X$ & 0.65 & 0.0001 \\
\hline \multirow[t]{2}{*}{ Hycrest } & Defoliated & $Y=-0.12-0.02 X$ & 0.00 & 0.45 \\
\hline & Undefoliated & $Y=-0.26-0.07 X$ & 0.22 & 0.0004 \\
\hline \multirow[t]{2}{*}{ Whitmar } & Defoliated & $Y=-0.31-0.08 X$ & 0.21 & 0.0005 \\
\hline & Undefoliated & $Y=-0.33-0.09 X$ & 0.31 & 0.0001 \\
\hline
\end{tabular}

tolerant species), root topology of defoliated plants did not change within $13 \mathrm{~d}$ of pot growth, but root biomass increased from 0.25 to $3.9 \mathrm{mg}$ in this time period (Fig. 4b). These results agreed with previous reports, which showed that grazing inhibited root extension and development in defoliated crested wheatgrass (Caldwell et al. 1981; Richards 1984). We are not aware of previous studies that reported positive changes of root biomass following defoliation as found in our study. In our study, the gain in root biomass might be explained by the observed increases in diameter of the main root axis and firstorder lateral roots of defoliated plants (Tables 2 and 3). This observation also challenges the general idea that defoliated grasses preferentially allocate biomass to recover photosynthetic tissue. We were able to observe this response because we included three harvests and examined root morphological trends through curve fitting. Our study results also differed from those of Arredondo and Johnson (1999), who found increased branching with defoliation. These latter results are consistent with those of Dawson et al. (2003), who reported changes in root topology and morphology in defoliated plants of perennial ryegrass (Lolium perenne L.) and sheep fescue (Festuca ovina L.), which depended upon nitrogen supply. Observed differences between studies may be due to nodal roots being used in the Dawson et al. (2003) study compared to seminal roots used in our study. Additional data are not available to generalize about this discrepancy.

Interestingly, root topology did not differ between defoliated and undefoliated plants for the grazing-sensitive Whitmar (Fig. 4c). This is similar to the results of Caldwell et al. (1981) and Richards (1984), who reported that bluebunch wheatgrass showed little change in root growth after defoliation. Although
Whitmar plants exhibited increased root biomass when defoliated, some growth inhibition was detected in defoliated plants compared to undefoliated plants (Fig. 4c). These results agree with our previous work, in which we observed that root foraging by Whitmar is topological-rather than proliferationbased (Arredondo and Johnson 1999). For defoliated plants of cheatgrass, both the rate of root topological change and root size were reduced, but these reductions were intermediate between those of Hycrest and Whitmar. Our analysis across all four species in our study also pointed out the negative impacts of defoliation on proliferation-compared to topological-based root responses (Table 6). These results supported our hypothesis that defoliation impacted proliferation-based responses to a greater degree than topological responses.

We are aware of the problems in generalizing the results of greenhouse studies to field plants. However, conducting initial studies of root morphology and topology in rangeland environments is problematic. Our greenhouse studies provide insights into possible root characteristics that may be important in understanding differences in root responses of rangeland grasses. Also, the three grasses used in our study exhibit different growth strategies, with cheatgrass being a winter annual, and Hycrest and Whitmar typically exhibiting spring or fall germination. The root responses observed in our study, however, agree with the results of previous studies conducted during spring and summer (Arredondo and Johnson 1998, 1999) and other studies conducted with the same grasses (Caldwell et al. 1981; Jackson and Caldwell 1989), which gives us confidence concerning the observed responses in our present study. Our greenhouse studies facilitated the control of various environmental factors, which allowed us to isolate morpho- 

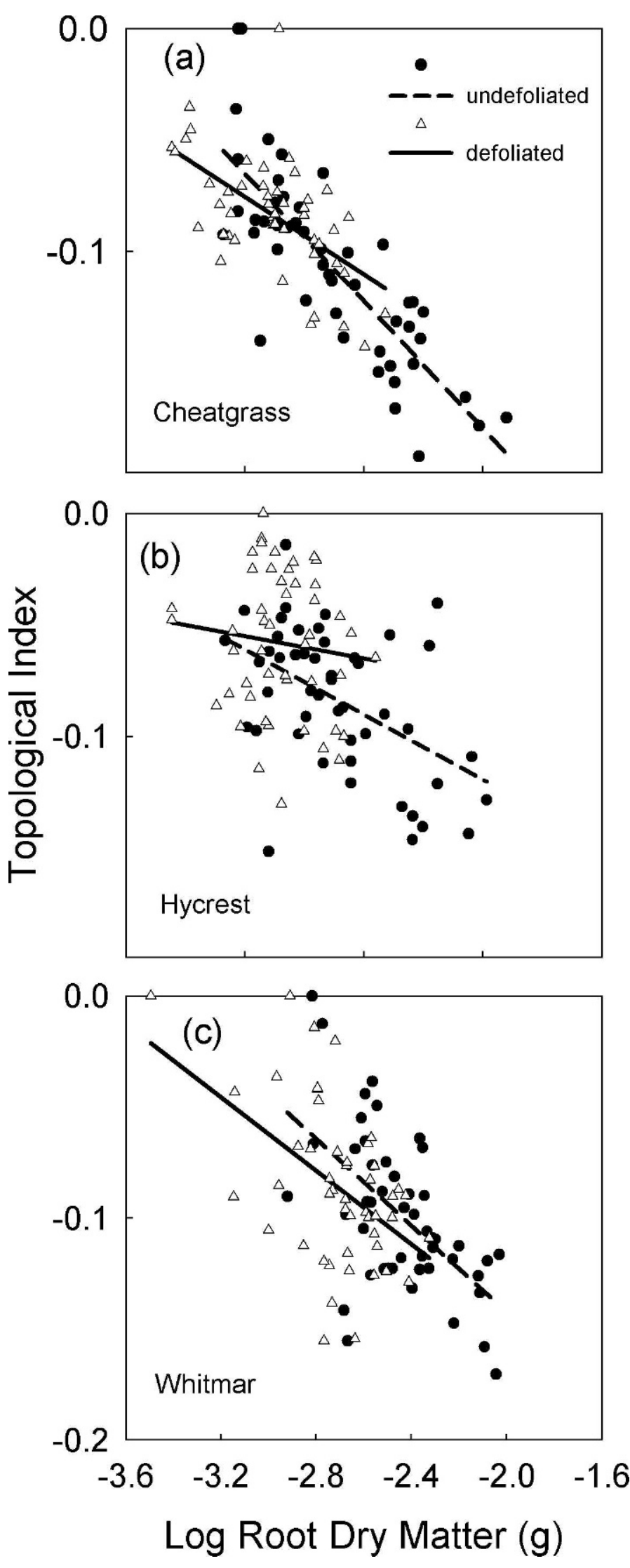

Figure 4. Least-square linear relationship between topological index and root dry matter (log scale) for a, cheatgrass; b, Hycrest; and c, Whitmar. Symbols correspond to the data points from which regression
Table 6. Proportional change in defoliated plants (\% of that for undefoliated plants) of total root length (TRL), topological index (TI, corrected for size), and number of root tips, averaged across three grass species in four nutrient treatments $(\mathrm{H}-\mathrm{H}$ indicates uniform-high; $\mathrm{H}-\mathrm{L}$, soil-nutrient depletion; $\mathrm{L}-\mathrm{L}$, uniform-low; and $\mathrm{L}-\mathrm{H}$, soil-nutrient pulse). For TI, positive changes indicate a reduction in branching complexity (e.g., herringbone topology).

\begin{tabular}{lccc}
\hline Soil nutrient treatment & TRL $(\%)$ & TI (\%) & No. of tips \\
\hline H-H & -59 & 4 & -94 \\
H-L & -72 & 16 & -31 \\
L-L & -31 & 0 & -26 \\
L-H & -69 & 23 & -2 \\
\hline
\end{tabular}

logical and topological root responses for several species. This would be almost impossible to accomplish under field conditions. Additionally, results from greenhouse studies can assist in identifying critical hypotheses to test for evaluating species performance in field environments.

\section{IMPLICATIONS}

Despite the limitations of this study being conducted in a greenhouse, our results provided an assessment of the responses of root foraging in relation to nutrient pulses and defoliation for three important rangeland grasses. Seedlings are a crucial phase for species continuity in rangeland ecosystems and contribute to community-level processes such as plant succession and community structure (Crawley 1983; Hulme 1996; Burt-Smith et al. 2003). In addition, seedling establishment is critical in the revegetation and restoration of degraded rangelands. Gaining a clearer understanding of root foraging responses to multiple factors such as soil nutrients and defoliation can help identify critical factors for selecting superior genotypes in plant improvement programs. Such information also may help to elucidate possible management tools that could be beneficial in reducing seedling mortality and improving seedling establishment. This is especially important in re-establishing perennial plant cover and diversity on cheatgrass-infested semiarid rangelands.

\section{ACKNOWLEDGMENTS}

We thank A. H. Fitter for providing the information to develop the topological index, and greatly appreciate the logistical support provided by K. Connors. We also thank E. Huber-Sannwald and two anonymous reviewers for their helpful comments on previous version of this manuscript.

\section{$\leftarrow$}

lines were estimated for defoliated plants (open triangles) and undefoliated plants (solid circles). 


\section{LITERATURE CITED}

Aanderud, Z. T., C. S. Bledsoe, and J. H. Richards. 2003. Contribution of relative growth rate to root foraging by annual and perennial grasses from California oak woodlands. Oecologia 136:424-430.

Aiken, R. M., And A. J. M. Smucker. 1996. Root system regulation of whole plant growth. Annual Review of Phytopathology 34:325-346.

Arredondo, J. T., And D. A. Johnson. 1998. Clipping effects on root architecture and morphology of 3 range grasses. Journal of Range Management 51:214220.

Arredondo, J. T., AND D. A. Johnson. 1999. Root architecture and biomass allocation of three range grasses in response to non-uniform supply of nutrients and shoot defoliation. New Phytologist 143:373-385.

Arredondo, J. T., T. A. Jones, And D. A. Johnson. 1998. Seedling growth of intermountain perennial and weedy annual grasses. Journal of Range Management 51:584-589.

Berntson, G. M. 1992. A computer program for characterizing root system branching pattern. Plant and Soil 140:145-149.

Bilbrough, C. T., and M. M. Caldwell. 1995. The effects of shading and N status on root proliferation in nutrient patches by the perennial grass Agropyron desertorum in the field. Oecologia 103:10-16.

Bilbrough, C. T., and M. M. Caldwell. 1997. Exploitation of springtime ephemeral N pulses by six Great Basin plant species. Ecology 70:231-243.

Brown, V. K., and A. C. Gange. 1992. Secondary plant succession: how is it modified by insect herbivory? Vegetatio 101:3-13.

Burt-Smith, G. S., J. P. Grime, and D. Tilman. 2003. Seedling resistance to herbivory as a predictor of relative abundance in a synthesized prairie community. Oikos 101:345-353.

Caldwell, M. M., J. H. Richards, D. A. Johnson, R. S. Nowak, and R. S. Dzurec. 1981. Coping with herbivory: photosynthetic capacity and resource allocation in two semiarid Agropyron bunchgrasses. Oecologia 50:14-24.

Chapin, F. S., III, and M. SLACK. 1979. Effect of defoliation upon root growth, phosphate absorption and respiration in nutrient-limited tundra graminoids. Oecologia 42:67-79.

Crawley, M. J. 1983. Herbivory. The dynamics of animal-plant interactions. Oxford, United Kingdom: Blackwell Scientific. 420 p.

CRIDER, F. J. 1955. Root-growth stoppage resulting from defoliation of grass. USDA Technical Bulletin No. 1102. Washington, DC, USA: US Department of Agriculture.

Davidson, D. W. 1993. The effects of herbivory and granivory on terrestrial plant succession. Oikos 68:23-35.

Dawson, L. A., B. Thornton, S. M. Pratt, and E. Paterson. 2003. Morphological and topological responses of roots to defoliation and nitrogen supply in Lolium perenne and Festuca ovina. New Phytologist 161:811-818.

Eissenstat, D. M., C. E. Wells, R. D. Yanal, and J. L. Whitbeck. 2000. Building roots in a changing environment: implications for root longevity. New Phytologist 147:33-42.
FitTeR, A. H. 1985. Functional significance of root morphology and root system architecture. In: A. H. Fitter, D. Atkinson, D. J. Read, and M. B. Usher [EDs.]. Ecological interactions in soil: plants, microbes, and animals. Oxford, United Kingdom: Blackwell Scientific. p. 87-106.

Fransen, B., H. de Kroon, C. G. F. de Kovel, and F. Van den Bosch. 1999. Disentangling the effects of root foraging and inherent growth rate on plant biomass accumulation in heterogeneous environments: a modeling study. Annals of Botany 84:305-311.

Gunn, S., S. J. Balley, and J. F. FarRar. 1999. Partitioning of dry mass and leaf area within plants of three species grown at elevated $\mathrm{CO}_{2}$. Functional Ecology 15:3-11.

HEwITT, E. J. 1966. Sand and water culture methods used in the study of plant nutrition. 2nd ed. East Malling, Kent, United Kingdom: Commonwealth Agricultural Bureau, Tech. Commun. No. 22. 547 p.

HuLme, P. E. 1996. Herbivory, plant regeneration and species coexistence. Journal of Ecology 84:609-615.

Hummel, I., D. Vile, C. Violle, J. Devaux, J. Ricci, A. Blanchrard, E. Garnier, and C. Roumet. 2007. Relating root structure and anatomy to whole-plant functioning in 14 herbaceous Mediterranean species. New Phytologist 173: 313-321.

Jackson, R. B., and M. M. Caldwell. 1989. The timing and degree of root proliferation in fertile-soil microsites for three cold-desert perennials. Oecologia 81:149-153.

Jackson, R. B., and M. M. Caldwell. 1991. Kinetic responses of Pseudoregneria roots to localized soil enrichment. Plant and Soil 138:231-238.

Jackson, R. B., and M. M. Caldwell. 1993. Geostatistical patterns of soil heterogeneity around individual perennial plants. Journal of Ecology 81:683-692.

Kembel, S. W., and J. F. CAhILL. 2005. Plant phenotypic plasticity belowground: a phylogenetic perspective on root foraging trade-offs. The American Naturalist 166:216-230.

Mokany, K., R. J. Raison, and A. S. Prokushkin. 2006. Critical analysis of root:shoot ratios in terrestrial biomes. Global Change Biology 12:84-96.

NIKLAS, K. J. 1994. Plant allometry. The scaling of form and process. Chicago, IL, USA: University of Chicago Press. 393 p.

Richards, J. H. 1984. Root growth response to defoliation in two Agropyron bunchgrasses: field observations with an improved root periscope. Oecologia 64:21-25.

SmART, J. S. 1978. The analysis of drainage network composition. Earth Surface Processes 3:129-170.

Sokal, R. R., ANd F. J. Rohlf. 1981. Biometry. New York, NY, USA: W.H. Freeman. $887 \mathrm{p}$.

TILMAN, D. 1988. Plant strategies and the dynamics and structure of plant communities. Monographs in population biology no. 26. Princeton, NJ, USA: Princeton University Press. $360 \mathrm{p}$.

Werner, C., and J. S. Smart. 1973. Some new methods of topologic classification of channel networks. Geographical Analysis 5:271-295.

Zar, J. H. 1984. Biostatistical analysis. Englewood Cliffs, NJ, USA: Prentice-Hall. $718 \mathrm{p}$. 